\title{
THERMAL BURNS IN MAN. IX. URINARY AMINO ACID PATTERNS ${ }^{1}$
}

\author{
By CHARLES H. EADES, JR., ${ }^{2}$ ROBERT L. POLLACK, ${ }^{3}$ and JAMES D. HARDY 4 \\ (From the Department of Biochemistry and Department of Surgery and Surgical Laboratories, \\ The University of Tennessee, Memphis, Tenn.)
}

(Submitted for publication May 6, 1955; accepted August 24, 1955)

It is a well known phenomenon that burned patients lose considerable amounts of nitrogenous materials following the initial trauma. They continue to stay in negative nitrogen balance for several days or even a month or more despite efforts to supply quantities of the necessary amino acids for metabolism and repair. Even though much protein material is lost in exudates (1), considerable amounts of catabolic nitrogenous substances appear in the urine. Besides the urea, creatinine, uric acid, and ammonia, relatively large amounts of amino acids and amino acid derivatives are excreted. This increase in the loss of amino acids is of special interest since it represents, for the most part, a wastage of materials needed for replacement and repair of the injured tissue.

In a recent paper Nardi (2) has studied the excretion of the free amino acids in urine of the burned patient by qualitative paper chromatographic techniques. In the study reported here, the quantitative determination of the amounts of 16 amino acids excreted in the urine following burn trauma has been studied in 9 patients to define with more exactness the qualitative and the quantitative aspects of the amino acid loss. In order to determine with greater clarity the amino acid patterns in urines of these burned patients, the amount of "free" amino acid and the "total" amount of each amino acid were determined. The amount of each amino acid in the "bound" form was determined by the difference between the two values found.

1 This work was performed under Army Contract No. DA-49-007-MD-296 between the University of Tennessee and the Office of the Surgeon General, Department of the Army.

2 Present Address: Mead Johnson Research Laboratories, Evansville, Indiana.

3 Present Address: U. S. Dept. Agricul., Eastern Region Utilization Branch, Philadelphia, $\mathrm{Pa}$.

4 Present Address: Department of Surgery, Medical College of the University of Mississippi, Jackson, Mississippi.

\section{METHODS}

Patients with burns involving more than 15 per cent of the body surface were examined in the emergency ward by the burn study team and then admitted to the metabolic ward where initial clinical measurements were made. The patients were then placed on a program of fluid therapy approximating that suggested by Evans, Purnell, Robinett, Batchelor, and Martin (3). This consistent policy was required to permit comparison among patients. The details of studies on these patients, other than the amino acid excretion studies, appear elsewhere. Description of each patient included in this report has already been published (4).

As soon as was feasible, usually about 48 hours following admission to the hospital, the patient was placed on a standardized liquid oral diet. It was of known content both as to quality and quantity of the various components. Amino acids were supplied in the diet as whole natural protein. This standard diet procedure was used in order to eliminate any metabolic variations in the excretion of amino acids that might occur from variations in the quantity or quality of the amino acid source ingested.

The patient was continued on the diet for at least four days. Complete urine collections were made and an aliquot of the collection on the fourth day of the diet was analyzed for the amino acid content. During late convalescence from the burn, usually just prior to discharge from the hospital, the diet was again administered to five of the nine patients for four days and urines again collected. On several occasions the patients were readmitted to the hospital for these latter studies. Thus in a measure the patient served as his own control for estimation of the change in the amino acid excretion brought about by the trauma of the burn.

The methods of handling the urines and performing the microbiological assays for the amino acids are those described by Eades and Pollack (5). In general, the method involved the microbiological assay of 16 amino acids using a uniform medium and one microorganism, Leuconostoc mesenteroides P-60 ATCC No. 8042. Amino acids in the urine were determined quantitatively both in "free" and "total" amounts. The "free" amount of each acid was assayed in a urease treated aliquot of the original urine while the "total" amount was determined in an acid hydrolyzed aliquot of the original urine. Cystine and tryptophan were not assayed in the hydrolyzed samples as there was destruction of these two in the hydrolysis procedures. 
BURNS IN MAN-URINARY AMINO ACID PATTERNS

TABLE I

Amino acids excreted by burned patients (mg./24 hrs.)

\begin{tabular}{|c|c|c|c|c|c|c|c|c|c|c|}
\hline Patient & \multicolumn{2}{|c|}{ J. H. } & \multicolumn{2}{|c|}{ T. S. } & \multicolumn{2}{|c|}{ L. $O$. } & \multicolumn{2}{|c|}{ M. L. } & \multicolumn{2}{|c|}{ G. S. } \\
\hline \% Burn & \multicolumn{2}{|c|}{$55 \%$} & \multicolumn{2}{|c|}{$17 \%$} & \multicolumn{2}{|c|}{$22 \%$} & \multicolumn{2}{|c|}{$18 \%$} & \multicolumn{2}{|c|}{$35 \%$} \\
\hline Days Post-burn & \multicolumn{2}{|c|}{6} & \multicolumn{2}{|c|}{6} & \multicolumn{2}{|c|}{6} & \multicolumn{2}{|c|}{6} & \multicolumn{2}{|c|}{6} \\
\hline Amino Acid & Free & Total & Free & Total & Free & Total & Free & Total & Free & Total \\
\hline $\begin{array}{l}\text { Glycine } \\
\text { L. Glutamic Acid } \\
\text { L. Aspartic Acid } \\
\text { L. Leucine } \\
\text { L. Valine } \\
\text { L. Phenylalanine } \\
\text { L. Threonine } \\
\text { L. Lysine } \\
\text { L. Isoleucine } \\
\text { L. Arginine } \\
\text { L. Histidine } \\
\text { L. Proline } \\
\text { L. Tyrosine } \\
\text { L. Methionine } \\
\text { L. Tryptophan } \\
\text { L. Cystine }\end{array}$ & $\begin{array}{l}602 \\
0-\mathrm{T} . * \\
0-\mathrm{T} . \\
19.0 \\
8.0 \\
50.9 \\
0-\mathrm{T} . \\
25.0 \\
0-\mathrm{T} . \\
0-\mathrm{T} . \\
134 \\
112 \\
50.2 \\
29.3 \\
40.1 \\
244\end{array}$ & $\begin{array}{c}803 \\
1,026 \\
613 \\
234 \\
201 \\
234 \\
195 \\
178 \\
78.1 \\
335 \\
185 \\
491 \\
223 \\
112 \\
-\end{array}$ & $\begin{array}{l}480 \\
0-\mathrm{T} . \\
50.4 \\
27.0 \\
35.3 \\
97.0 \\
85.0 \\
61.6 \\
20.4 \\
42.0 \\
148 \\
73.0 \\
156 \\
22.0 \\
58.0 \\
126\end{array}$ & $\begin{array}{l}850 \\
640 \\
390 \\
130 \\
212 \\
258 \\
140 \\
196 \\
75 \\
80 \\
188 \\
180 \\
260 \\
90.1 \\
-\end{array}$ & $\begin{array}{c}278 \\
0-\mathrm{T} . \\
40.3 \\
26.8 \\
20.3 \\
43.4 \\
98.0 \\
74.9 \\
19.8 \\
0-\mathrm{T} . \\
230 \\
42.8 \\
78.0 \\
19.4 \\
53.5 \\
168\end{array}$ & $\begin{array}{l}578 \\
779 \\
182 \\
126 \\
123 \\
52.5 \\
133 \\
213 \\
96.3 \\
55.6 \\
250 \\
152 \\
227 \\
32.5 \\
- \\
-\end{array}$ & $\begin{array}{c}345 \\
0-\mathrm{T} . \\
177 \\
41.3 \\
62.7 \\
39.7 \\
80.0 \\
158 \\
7.3 \\
0-\mathrm{T} . \\
390 \\
18.6 \\
159 \\
15.7 \\
95.0 \\
198\end{array}$ & $\begin{array}{l}755 \\
580 \\
645 \\
178 \\
156 \\
186 \\
210 \\
236 \\
189 \\
146 \\
395 \\
131 \\
221 \\
37.6 \\
-\end{array}$ & $\begin{array}{l}482 \\
0-\mathrm{T} . \\
23.8 \\
38.5 \\
36.2 \\
28.0 \\
0-\mathrm{T} . \\
43.2 \\
45.0 \\
0-\mathrm{T} . \\
211 \\
23.0 \\
66.7 \\
10.3 \\
68.6 \\
220\end{array}$ & $\begin{array}{r}862 \\
896 \\
1,030 \\
420 \\
455 \\
158 \\
331 \\
399 \\
319 \\
508 \\
438 \\
456 \\
301 \\
99.6 \\
- \\
-\end{array}$ \\
\hline
\end{tabular}

TABLE I-Continued

Amino acids excreted by burned patients (mg./24 hrs.)

\begin{tabular}{|c|c|c|c|c|c|c|c|c|}
\hline Patient & \multicolumn{2}{|c|}{ A. Ni. } & \multicolumn{2}{|c|}{ O. H. } & \multicolumn{2}{|c|}{ M. $\mathbf{R}$. } & \multicolumn{2}{|c|}{ R. J. } \\
\hline$\%$ Burn & \multicolumn{2}{|c|}{$40 \%$} & \multicolumn{2}{|c|}{$25 \%$} & \multicolumn{2}{|c|}{$23 \%$} & \multicolumn{2}{|c|}{$55 \%$} \\
\hline Days Post-burn & \multicolumn{2}{|c|}{8} & \multicolumn{2}{|c|}{7} & \multicolumn{2}{|c|}{5} & \multicolumn{2}{|c|}{11} \\
\hline Amino Acid & Free & Total & Free & Total & Free & Total & Free & Total \\
\hline $\begin{array}{l}\text { Glycine } \\
\text { L. Glutamic Acid } \\
\text { L. Aspartic Acid } \\
\text { L. Leucine } \\
\text { L. Valine } \\
\text { L. Phenylalanine } \\
\text { L. Threonine } \\
\text { L. Lysine } \\
\text { L. Isoleucine } \\
\text { L. Arginine } \\
\text { L. Histidine } \\
\text { L. Proline } \\
\text { L. Tyrosine } \\
\text { L. Methionine } \\
\text { L. Tryptophan } \\
\text { L. Cystine }\end{array}$ & $\begin{array}{c}181 \\
46.2 \\
77.2 \\
3.6 \\
3.4 \\
24.5 \\
0-\mathrm{T} . \\
33.2 \\
0-\mathrm{T} . \\
0-\mathrm{T} . \\
158 \\
0-\mathrm{T} . \\
60.9 \\
11.3 \\
69 \\
54.1\end{array}$ & $\begin{array}{c}1,126 \\
399 \\
266 \\
92.4 \\
115 \\
460 \\
124 \\
133 \\
110 \\
155 \\
218 \\
159 \\
125 \\
40.0 \\
= \\
-\end{array}$ & $\begin{array}{l}432 \\
0-\mathrm{T} . \\
60.0 \\
15.0 \\
28.3 \\
56.3 \\
143 \\
50.6 \\
37.5 \\
16.2 \\
318 \\
125 \\
138 \\
23.5 \\
67.5 \\
270\end{array}$ & $\begin{array}{l}950 \\
752 \\
792 \\
190 \\
242 \\
255 \\
420 \\
321 \\
236 \\
152 \\
680 \\
330 \\
188 \\
48.0 \\
-\end{array}$ & $\begin{array}{l}445 \\
0-\mathrm{T} . \\
49.8 \\
5.8 \\
0-\mathrm{T} . \\
18.6 \\
0-\mathrm{T} . \\
43.9 \\
0-\mathrm{T} . \\
0-\mathrm{T} . \\
91.3 \\
87.8 \\
14.9 \\
25.4 \\
12.2 \\
223\end{array}$ & $\begin{array}{l}730 \\
240 \\
220 \\
94.6 \\
94.7 \\
89.6 \\
50.0 \\
74.4 \\
52.7 \\
57.5 \\
156 \\
129 \\
62.5 \\
60.8 \\
- \\
-\end{array}$ & $\begin{array}{l}203 \\
0-\mathrm{T} . \\
34.7 \\
15.4 \\
0-\mathrm{T} . \\
35.0 \\
56.0 \\
26.1 \\
16.3 \\
24.2 \\
129 \\
23.9 \\
65.3 \\
37.3 \\
57.8 \\
224\end{array}$ & $\begin{array}{r}1,119 \\
670 \\
159 \\
286 \\
285 \\
187 \\
452 \\
410 \\
332 \\
212 \\
185 \\
466 \\
231 \\
119 \\
-\end{array}$ \\
\hline
\end{tabular}

* $0-\mathrm{T}$. - Zero to trace quantities by microbiological assay.

\section{RESULTS}

The amounts of the 16 amnio acids excreted in 24 hours by nine burned patients are shown in Table I in both "free" and "total" s amounts. In Table II, values for the amino acids excreted by five of these patients late in convalescence are shown. For comparison the mean normal values, with the standard error, for 10 normal subjects (5) are included to show that upon recovery from the burn trauma, the amino acid values approach normalcy again. Statistical evaluation of the data

\footnotetext{
Except cystine and tryptophan.
}

on the burned, as compared to the recovered patient, was made using the "student's" $t$ Method (6). The probability level arbitrarily considered significant in this evaluation was that the difference between means could occur by chance alone less than 5 per cent of the time $(P<0.05)$. Of the 14 amino acids evaluated (excluding tryptophan and cystine) only 4, aspartic acid, isoleucine, proline, and valine, gave $P$ values greater than 0.05 . With the exception of isoleucine even these amino acids had $P$ values between 0.05 and 0.1 . For most of the amino acids the $P$ values were between 0.02 and 0.05 with tyrosine giving a value $<0.001$. 
TABLE II

Amino acids excreted by convalescent burned patients (mg./24 hrs.)

\begin{tabular}{|c|c|c|c|c|c|c|c|c|c|c|c|c|}
\hline Patient & \multicolumn{2}{|c|}{ J. H. } & \multicolumn{2}{|c|}{ T.S. } & \multicolumn{2}{|c|}{ L. $O$. } & \multicolumn{2}{|c|}{ M. L. } & \multicolumn{2}{|c|}{ G. S. } & \multirow{3}{*}{\multicolumn{2}{|c|}{$\begin{array}{l}\text { Mean normal } \\
\text { values (3) } \\
\text { ms. } / 24 \text { hrs. }\end{array}$}} \\
\hline$\%$ Burn & \multirow{2}{*}{\multicolumn{2}{|c|}{$\begin{array}{l}55 \% \\
95\end{array}$}} & \multirow{2}{*}{\multicolumn{2}{|c|}{$\begin{array}{l}17 \% \\
85\end{array}$}} & \multirow{2}{*}{\multicolumn{2}{|c|}{$\frac{22 \%}{24}$}} & \multicolumn{2}{|c|}{$18 \%$} & \multirow{2}{*}{\multicolumn{2}{|c|}{$35 \%$}} & & \\
\hline Days Post-burn & & & & & & & 62 & & & & & \\
\hline Amino Acid & Free & Total & Free & Total & Free & Total & Free & Total & Free & Total & Free* & Total* \\
\hline $\begin{array}{l}\text { Glycine } \\
\text { L. Glutamic Acid } \\
\text { L. Aspartic Acid } \\
\text { L. Leucine } \\
\text { L. Valine } \\
\text { L. Phenylalanine } \\
\text { L. Threonine } \\
\text { L. Lysine } \\
\text { L. Isoleucine } \\
\text { L. Arginine } \\
\text { L. Histidine } \\
\text { L. Proline } \\
\text { L. Tyrosine } \\
\text { L. Methionine } \\
\text { L. Tryptophan } \\
\text { L. Cystine }\end{array}$ & $\begin{array}{l}199 \\
0-\mathrm{T} . \\
31.5 \\
14.0 \\
0-\mathrm{T} . \\
4.5 \\
0-\mathrm{T} . \\
12.5 \\
15.2 \\
0-\mathrm{T} . \\
40.0 \\
10.9 \\
9.3 \\
13.9 \\
12.0 \\
71.2\end{array}$ & $\begin{array}{c}353 \\
161 \\
176 \\
45.6 \\
100 \\
24.8 \\
44.9 \\
46.4 \\
41.2 \\
52.8 \\
60.8 \\
57.6 \\
42.1 \\
25.6 \\
-\end{array}$ & $\begin{array}{c}296 \\
0-\mathrm{T} . \\
0-\mathrm{T} . \\
13.0 \\
19.4 \\
19.4 \\
24.1 \\
25.0 \\
32.2 \\
0-\mathrm{T} . \\
139 \\
11.0 \\
54.4 \\
0-\mathrm{T} . \\
25.0 \\
79.4\end{array}$ & $\begin{array}{c}400 \\
232 \\
269 \\
87.5 \\
110 \\
73.2 \\
90.0 \\
115 \\
90.7 \\
69.5 \\
149 \\
111 \\
90.0 \\
20.0 \\
- \\
-\end{array}$ & $\begin{array}{c}219 \\
0-\mathrm{T} . \\
30.3 \\
5.5 \\
0-\mathrm{T} . \\
14.7 \\
0-\mathrm{T} . \\
0-\mathrm{T} . \\
20.6 \\
0-\mathrm{T} . \\
120 \\
22.2 \\
53.4 \\
18.0 \\
13.4 \\
69.4\end{array}$ & $\begin{array}{c}395 \\
132 \\
201 \\
29.4 \\
40.1 \\
28.9 \\
88.0 \\
72.1 \\
67.7 \\
50.9 \\
145 \\
99.7 \\
92.5 \\
31.8 \\
- \\
-\end{array}$ & $\begin{array}{c}118 \\
0-\mathrm{T} . \\
26.5 \\
8.0 \\
7.9 \\
19.0 \\
12 \\
26.8 \\
22.8 \\
0-\mathrm{T} . \\
132 \\
9.3 \\
26.0 \\
4.2 \\
19.4 \\
76.0\end{array}$ & $\begin{array}{c}314 \\
288 \\
191 \\
29.5 \\
33.0 \\
32.4 \\
27.0 \\
65.6 \\
36.4 \\
43.7 \\
136 \\
59.0 \\
70.4 \\
16.4 \\
- \\
-\end{array}$ & $\begin{array}{l}145 \\
0-\mathrm{T} . \\
52 \\
16.5 \\
18.9 \\
13.3 \\
0-\mathrm{T} . \\
75.6 \\
22.5 \\
0-\mathrm{T} . \\
25.6 \\
8.8 \\
22.4 \\
3.0 \\
9.3 \\
29\end{array}$ & $\begin{array}{c}503 \\
586 \\
200 \\
57 \\
30.5 \\
37.0 \\
73.0 \\
155 \\
33.6 \\
184 \\
46.4 \\
97.0 \\
70.1 \\
30 \\
- \\
-\end{array}$ & $\begin{array}{r}226 \pm 15 \\
1 \pm 1 \\
12 \pm 2 \\
9 \pm 1 \\
9 \pm 3 \\
15 \pm 3 \\
19 \pm 4 \\
18 \pm 3 \\
4 \pm 1 \\
2 \pm 1 \\
125 \pm 11 \\
6 \pm 1 \\
27 \pm 3 \\
9 \pm 3 \\
-\end{array}$ & $\begin{array}{r}405 \pm 42 \\
170 \pm 27 \\
161 \pm 13 \\
33 \pm 2 \\
35 \pm 5 \\
25 \pm 3 \\
40 \pm 4 \\
52 \pm 6 \\
24 \pm 3 \\
22 \pm 3 \\
171 \pm 27 \\
33 \pm 3 \\
48 \pm 6 \\
26 \pm 7 \\
= \\
-\end{array}$ \\
\hline
\end{tabular}

* \pm Value is the standard error of mean.

At the 5 per cent statistical level no significant difference between the amount of the various amino acids excreted by the normal control and the recovered burn patient could be shown with the possible exception of aspartic acid, isoleucine, and proline. It should be kept in mind, however, that statistical evaluation of so few data is not quite reassuring and with a few more data these differences might not be significant.

A comparison of the data of the controls with the data of the burned patients yielded results comparable to the comparison of the burned with the recovered patients.

\section{DISCUSSION}

From the tables it can be seen that all 16 of the amino acids assayed were excreted in higher amounts by the 5 patients in the immediate postburn period than were excreted by the same patients later in convalescence. For all 9 patients the same holds true when comparison is made to the excretion values of the 10 normal subjects. The amounts of the bound forms of the amino acids appearing in the urine immediately following the burn are considerable but decrease in quantity as recovery progresses. The amount of bound histidine, however, is not great in either the early or late samples. Three other amino acids, threonine, isoleucine, and methionine, are variable in the amounts of bound forms excreted by the various patients but they are somewhat lower than most of the amino acids. Protein was not detected in the urines that were assayed for the amino acids; therefore the bound forms would appear to represent peptides, conjugates, or other forms of amino acid derivatives. This "bound form" aspect of the amino-aciduria is of considerable interest $(7,8)$, as it may yield information on intermediary metabolism and metabolic pathways of amino acid utilization.

Most striking is the amount of bound glutamic acid that is lost during the immediate post-burn period and the absence, or nearly so, of the free glutamic acid in all but one of the samples, burn or normal, that were assayed. Glutamine is present in the urine and may account for some of the bound form. The amount of bound aspartic acid is also considerable in the urine of the recently burned patient, but the value returns to normal with recovery. Another most interesting observation is that glycine is excreted in relatively large amounts, free and bound, immediately postburn. This increase follows closely the rise of many other metabolites found in the urine. Of particular interest is the parallelism of the adrenocortical response to the burn trauma and the increase of the excretion of amino acids. The amounts of the corticoids excreted are usually high immediately after the burn and return to a normal value upon recovery (4). This increase in urinary corticoids may in part account for some of the bound glycine excreted (8) the gly- 
cine being bound in some fashion to the steroid. Especially does this seem plausible since it has been reported (9) that the steroid content of urine increases following enzymatic or acid hydrolysis. This treatment also gives rise to more free amino acids.

Of all 16 amino acids that were quantitatively assayed, relatively few were found to be absent, or in trace amounts, in the free state and none was absent when the hydrolyzed samples were tested. Even though results are not reported in this paper on the excretion values for alanine or serine, due to the variable results obtained in our assay, the findings in our laboratory are that alanine and serine both are excreted in appreciable amounts. Our consistent microbiological assay results showing the presence of free tyrosine, tryptophan, and phenylalanine in every case are in contrast somewhat to the report of Nardi (2) who showed free tyrosine in only one case. Of the fourteen urines assayed, free arginine was low or absent in eleven, free valine in four and free threonine in five. Free aspartic acid was found in all but two of the fourteen samples. Whether the aspartic acid was excreted in the free state or in some relatively labile bound form has not been definitely determined.

Our results tend to support the idea that the severity of the burn influences the degree of the amino acid loss in the urine. Especially does this seem to be evident in the amount of the bound forms excreted. The increase in the amino acids in the urine may be due to an increased demand for amino acids for the repair of the injured tissues, possibly controlled by some mechanism mediated through the pituitary-adrenal system, as an increase in the corticoids accompanies this phenomenon. Since it has been demonstrated that an increase in amino acid output follows the injection of ACTH (10), it is reasonable to assume that trauma from burns will cause a concomitant rise in ACTH and consequently an increase in aminoaciduria. These facts implicate the general body reaction to stress as being, in part at least, responsible for the often detected increase in amino acid loss in many traumatic conditions be they mild or severe. Whether this alarm response affects the excretion mechanism of the kidney or simply raises the level of the plasma amino acids above the functioning threshold has not been settled.

\section{SUMMARY}

The excretion patterns of 16 amino acids have been determined in the urine of patients immediately post-burn and later in convalescence. The amounts of free and bound forms of the amino acids are greater in the immediate post-burn period than in the later period of convalescence. Large amounts of glutamic acid are found in the bound form with none or only a trace appearing in the free form in both the burned and normal patient's urine. Likewise glycine is excreted in large amounts, free and combined, immediately postburn. The values return to normal upon recovery. Of all 16 amino acids that were quantitatively assayed relatively few were absent as free amino acids and none were absent when the hydrolyzed urines were tested. Our results for the most part tend to support the idea that the severity of the burn bears a close relationship to the degree of the amino acid loss in the urine.

\section{REFERENCES}

1. Moore, F. D., Langohr, J. L., Ingebretsen, M., and Cope, O., The role of exudate losses in the protein and electrolyte imbalance of burned patients. Ann. Surg., 1950, 132, 1.

2. Nardi, G. L., "Essential" and "nonessential" amino acids in the urine of severely burned patients. J. Clin. Invest., 1954, 33, 847.

3. Evans, E. I., Purnell, O. J., Robinett, P. W., Batchelor, A., and Martin, M., Fluid and electrolyte requirements in severe burns. Ann. Surg., 1952, 135, 804.

4. Wilson, H., Lovelace, J. R., and Hardy, J. D., The adrenocortical response to extensive burns in man. Ann. Surg., 1955, 141, 175.

5. Eades, C. H., Jr., and Pollack, R. L., Urinary excretion of fourteen amino acids by normal and cancer subjects. J. Nat. Cancer Inst., 1954, 15, 421.

6. Snedecor, G. W., Statistical Methods Applied to Experiments in Agriculture and Biology, 4th ed., Ames, Iowa State College Press, 1946.

7. Pollack, R. L., and Eades, C. H., Jr., Glucuronic acid conjugates of aspartic and glutamic acids in urine. Science, 1954, 119, 510.

8. Eades, C. H., Jr., Pollack, R. L., and King, J. S., Jr., An amino acid-steroid conjugate excreted in urine. Federation Proc., 1954, 13, 201.

9. Venning, E. H., Dyrenfurth, I., and Kazmin, V. E., Hydrolysis and extraction of corticoids and 17ketosteroids from body fluids. Recent Prog. Hormone Research, 1953, 8, 27.

10. Ronzoni, E., Roberts, E., Frankel, S., and Ramasarma, G. B., Influence of administration of ACTH on urinary amino acids. Proc. Soc. Exper. Biol. \& Med., 1953, 82, 496. 